\title{
The Eternal God's Response to Man's Cry in His Passing "Days" and "Years" (Ps 90)
}

\author{
HENRYK WITCZYK \\ Institute of Biblical Studies, John Paul II Catholic University of Lublin \\ e-mail: henwit@kul.lublin.pl \\ ORCID 0000-0003-4451-0697
}

\begin{abstract}
In Ps 90, the poet expresses his perception of man's time as marked by dynamic of passing away, fear of death, destruction, and futility. At the same time, he speaks of God's "eternity" as "You are" (v. 2). He discovers the astonishing influence of "eternity" on "time." The prayer of the "servants" makes the distant God (full of anger and indignation - v. 11) come close to them and act in their fleeting time to evoke His "mercy," "steadfast love," "joy" "glorious power," thereby making time "stable" and "permanent" (v. 17). This is anchored in God's eternity, even in God's "You are" (v. 2). In the short and transient "days" and "years" of His "servants" and their "sons," God writes an intense experience of His eternity. The extraordinary coexistence, even the interpenetration of time and eternity in the experience of the believer (people), is perhaps the most crucial theological intuition of Ps 90 .
\end{abstract}

Keywords: eternity, time, man's time, days and years, Ps 90

The authors of the Psalms do not use the philosophical concept of "time" or "eternity." They use the noun "time" (עת), which refers to a period of life or a specific moment when an action takes place. ${ }^{2}$ On the other hand, they recall a person's "days" or "years" several times (cf. Ps 90:4,9,10,12,14,15). ${ }^{3}$ They use

1 The theme of "time" is present primarily in Job 14:1-22 and Ecc 3:1-10. More extensive classical studies on "time" in the Bible include the following publications: J. Barr, Biblical Words for Time (SBT 33) (London: SCM 1962); J. Muilenburg, "The Biblical View of Time," HThR 54 (1961) 225-271; C.H. Ratschow, "Anmerkungen zur theologischen Auffassung des Zeitproblems," ZTK 51 (1954) 360-387; M. Sekine, "Erwägungen zur hebräischen Zeitauffassung," CongressVolume. Bonn 1962 (eds. G.W. Anderson et al.) (VTSup 9; Leiden: Brill 1963) 66-82; J.R. Wilch, Time and Event (Leiden: Brill 1969).

2 "Time" is defined by what happens in it. It is the time of events or phenomena taking place. This is perfectly evident in Ecc 3:1-3 (cf. 8:7; 10:14). Cf. R. Schmitt, Abschied von der Heilsgeschichte? Untersuchungen zum Verständnis von Geschichte im Alten Testament (EHS.T 195; Frankfurt am Main: Lang 1982) 103-104; the relationship between time in this sense and eternity is studied by Holger Gzella (Lebenszeit und Ewigkeit. Studien zur Eschatologie und Anthropologie des Septuaginta-Psalters [BBB 134; Berlin: Philo 2002]).

3 The division of time into "days" and "years" is not so much of a mathematical and abstract nature as it is related to human activity in the field, pasture, city and temple (holidays). Therefore, the basic unit for counting time is "days" (the rhythm of successive "days" and "nights"), and to a lesser extent "years." Cf. M. Köckert, "Zeit und Ewigkeit in Psalm 90," Zeit und Ewigkeit als Raum göttlichen 
the noun "days" as many as five times with a personal pronoun to create the phrase "my days" (ימי in Ps 39:6; 102:4,12,25; 144:4). Moreover, when the author of Ps 31:11 talks about years, he writes: "For my life is consumed with grief and my years with groaning" (שנותי). Other psalmists, on the other hand, combine the noun "years" with the third-person plural pronoun ("their years"- Ps 77:6; 78:33) or the first-person plural ("our years"- Ps 90:9). In this way, they give the "days" and "years" of man an existential characteristic next to the "spatial" one, which is quite visible in many psalms (the time related to action in a specific location - cf. Ps 104:22-23). In this way, the authors link time to a given community or person and their lives in a particular place. Generally, it is, above all, marked by a time of passing away, determined by the passing of days and years.

On the other hand, however, when speaking about man's time, psalmists usually evoke God's image and His continuance. What is more, man's passing time contrasts with God's unchangeable continuance "from everlasting to everlasting" (מעולם עד־עולם - Ps 90:2), meaning His eternity. ${ }^{5}$ It is not about eternity in the philosophical sense, but refers to God's existence, known for His generous love for Israel, which hovers over them in the form of a blessing: "And the Lord's love is with those who fear Him, and His righteousness with their children's children - with those who keep His covenant and remember to obey His precepts. The Lord has established His throne in heaven, and His kingdom rules over all" (Ps 103:17-19; cf. Ps 41:14; 106:48). The question, therefore, arises as to the relationship between God's eternity, who reigns in heaven (cf. Ps 90:1-2), and the passing of day after day and year after year for man, including the Israelite who believes in Him, who lives on earth and experiences the fragility, transience, suffering, and misery inherent to human nature (cf. v. 15).

This problem is particularly broadly taken up by the author of Psalm 90. First, he presents, in a manner characteristic of the ancient sapiential tradition, a wisdom meditation on the futility of man's time (vv. 3-10), which is determined by two factors: his passing away to death (vv. 3-6) and God's wrath due to guilt and

Handelns. Religionsgeschichtliche, theologische und philosophische Perspektiven (eds. R.G. KratzH. Spieckermann) (Berlin: De Gruyter 2009) 156.

$4 \quad$ Ps 39, which Manfred Oeming (Das Buch der Psalmen. Psalm 1-41 [NSKAT 13/1; Stuttgart: Katholisches Bibelwerk 2000] 213-215) writes about in terms of form and content, approximating the texts of Job and Ecclesiastes, is thematically closest to Ps 90. An important achievement of this sapiential reflection in the period of late Judaism was the discovery of man's smallness, randomness, and temporality, which the poet of Ps 39 undertakes in an extremely moving way. In turn, the extensive study in Ps 90, apart from the above-mentioned chapter in the collective work, is contained in the following publications: J. Schnocks, Vergänglichkeit und Gottesherrschaft. Studien zu Psalm 90 und dem vierten Psalmenbuch (BBB 140; Berlin: Philo 2002) 17-171; K. Seybold, "Zu den Zeitvorstellungen in Psalm 90," TZ 53 (1997) 97-108; R. Abelava, Le Psaume 90 et les fragilités humaines. Analyse sémantique et lecture contextuelle (Strasbourg: Université de Strasbourg 2012).

5 Cf. J. Schnocks, "“Ehe die Berge geboren wurden, bist du.' Die Gegenwart Gottes im 90. Psalm," BK 54 (1999) 163-169. 
sins (vv. 7-10). He summarizes this using classical sentences for this tradition: a rhetorical question concerning man's limited wisdom and a request for wisdom coming from God (vv. 11-12). This meditation, rooted in his existential and historical experience, ultimately gives birth to a prayer of supplication. Hans Joachim Kraus captures the relationship between man's time and God in Ps 90 in the words: "Lamentation on the passing of people before the eternal God."

The question arises whether the prayer of supplication is not about something more than a lamentation itself, namely, the answer (action) based on God's eternal life (vv. 13-16) to man's passing time (vv. 3-10). ${ }^{7}$ According to the author of Ps 90, is God's eternity a kind of response to man's "time?" Isn't this the case not in the sense of the length of time measured on a calendar, but rather when seen from the viewpoint of experiences, that is, marked by the factors mentioned above: human transience (impermanence) and God's wrath? If so, what is it, and above all, how can it be achieved?

As a new stage of existence, which only comes at the end of a man's life on earth as the New Testament mentions, doesn't God's eternity in some way become a part of a believing man and an Israelite's "now" here on earth in the present time or the near and able to be calculated future? If so, what does this share give him? What does experiencing this share indicate?Answers to these questions will be sought in analyzing the literary composition of Ps 90, the structure (the main semantic line) concerning the theme of time present in all its segments, inclusion (vv. 1-2:17), and individual structural components (vv. 3-6; 7-10;11-12; 13-16).

\section{The "Eternity - Time" Contrast in the Literary Composition of Ps 90}

Without knowing abstract words to describe "eternity" and "time," the authors of the biblical psalms are keen to use the juxtaposition of God's permanence "from

6 "Klage über die Vergänglichkeit der Menchen vor dem ewigen Gott" (H.-J. Kraus, Psalmen, 7 ed. [Neukirchen-Vluyn: Neukirchener 2003]II, 794).

7 Cf. E. Zenger, "The God of Israel's Reign over the World (Psalms 90-106)," The God of Israel and the Nations (eds. N. Lohfink - E. Zenger) (Collegeville, MN: Liturgical Press 2000) 164; these two literary genres are combined in the above-mentioned 11-12, and framed by the above-mentioned v. 1-2 and v. 17 form a compact literary whole that is Ps 90. Cf. Abelava, Le Psaume 90, 116-124; Pierre Auffret ("Essai sur la structure littéraire du Psaume 90," Bib 61 [1980] 262-276) tries to prove that Ps 90 is divided into two parts: 1-10; 11-17. However, this structure does not reflect the specificity of Ps 90 and their role in it. It is convincingly demonstrated by Robert Abelava as well as other commentators, e.g., S. Schreiner, "Erwägungen zur Struktur des 90. Psalms," Bib 59 (1978) $80-90$, who claims that v. 11 (in connection with v. 12) plays an absolutely central role in Ps 90, and the other verses are divided into two parts (I - vv. 3-10; II - vv. 13-16) that are correlated as follows: vv. 3-4 with v. 13 ; vv. 5-7 with v. 14 ; vv. 8-9 + 10 with v. $15+16$. Verses $1-2$ and 17 form an inclusion. 
age to age" (v. 1) and "from everlasting to everlasting" (v. 2) with man's "days" and "years" that passaway. ${ }^{8}$ The author of Ps 90 uses it. The poet develops these phrases through contrasts in a very pictorial, sophisticated, and lively manner. First, they concern God (vv. 2-4) and man (vv. 3:5-6), and at the same time they are juxtaposed with each other by applying parallelism, which is further emphasized by the following contrast:

God's eternity (v. 2) man in time (v. 3)

God's eternity (v. 4) man in his frailty (vv. 5-6)

This combination highlights the sharp contrast between God's eternity and man's time. It is seen as even more influential in the juxtaposition that the poet makes between God's eternity in v. 2 and the years of man's lifetime, being limited to 70 or 80 (v. 10). In turn, the contrast for man's "thousand years" is "one day" in God's eyes: "For in Your sight a thousand years are but a day that passes, or the watch of the night" (v. 4).

Moreover, in general, the "days" and "years" of a man's life, in contrast to God's eternity, are like a dream disappearing in the morning, wilted grass, or even a time of misery and woes (cf. vv. 5-6.15). ${ }^{9}$

Considering the literary genres of the verses that make up the contents of Ps 90, as well as their philological and semantic analysis, as mentioned above, Robert Abelava presented the literary composition of Ps 90 as a diptych based on the following chiastic pattern:
A: (vv. 1-2)
B: (vv. 3-10)
C: (vv. 11-12)
B': (vv. 13-16)
$\mathrm{A}^{\prime}:($ v. 17$){ }^{10}$

This proposal needs to be made more specific. Namely, in segment B (vv. 3-10) verses 3-6 clearly stand out in terms of vocabulary, which concern death as a factor written into man's time by God Himself: "You turn people back to dust" (v. 3a);

8 These nouns do not refer in this article to a philosophical or physical understanding of eternity and time. As indicated by the quoted verses of Ps 90, they point to man's (prayerful) experiences related to the lasting and unchanging, unharmed existence of God in heaven (in the heights), the transient and rapidly ending existence of man on earth.

9 The contrast between God's "eternity" and man's "time" made up of "days" and "years" is highlighted in his analysis of Ps 90's literary composition in terms of its symbolism by Gianfranco Ravasi, Il libro dei Salmi. II. Commento e attualizzazione (51-100) (Collana Lettura Pastorale della Bibbia 14; Bologna: EDB 1986) 877-879.

10 Cf. Abelava, Le Psaume 90, 117. 
a lifetime is like one day for grass that "by evening wilters and withers" (v. 6). In turn, in vv. 7-10, the topic of God's wrath dominates (vv. 7a, 9a), which makes the time "of our days a hardship and a waste," "for they pass away quickly, and we are gone" (v. 10). Finally, in a precise literary composition of Ps 90 by R. Abelava, one can find in vv. 1-2.17 an inclusion, and in vv. 6-10 a two-part meditation on the time of man marked by death (vv. 3-6) and God's wrath (vv. 7-10); vv. 11-12 pose a question and request for wisdom; vv. 13-16 is a prayer raised to God who is "from age to age" (v. 1b) and can act for "all our days" (v. 14b).

The presented literary composition of Ps 90 allows us to see a characteristic reversal of the prayerful man's way of seeing things: from the level of the limited, transient, and finite time of human existence towards the never-ending "eternal" existence of God, His eternity. Immersed in the passing "days" and "years" of his life, man (vv. 3-10) raises his cry to God (vv. 13-16), in which he asks for the specific completion of his time with God's gifts, of which "graciousness" comes first:

Satisfy us in the morning with thy generous goodness (חסדך),

that we may rejoice and be glad all our days (v. 14).

Only when the generous goodness of God and steadfast love (חס) rooted in His eternity completes man's "days" and "years" will they become a time of joy and cheerfulness. Moreover, even the days of God's punishment and misery can continue to be days of joy and cheerfulness. This will happen when God responds to the fervent request of people immersed in the misery of "days" and "years" of exile, as evidenced by the cry: "Return, O Lord! How long will it be? Have compassion on Your servants!" (v. 13). After showing mercy to the converting people, the prayerful man on their behalf trusts that God will fill the rest of his stay on earth with joy:

Make us glad for as many days as You have afflicted us,

For as many years as we have seen evil (v. 15).

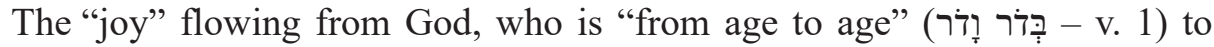
a person and all people can even be directly proportional in terms of its duration to the number of days and years of misery.

The literary composition of Ps 90 created by the final editor, in which the mentioned earlier vv. 1-2 and v. 17 are firmly connected, presents a great truth about man's time. God's majestic eternity (vv. 1-2) is directed towards the people (and individual believers) and their experience of time. The truth of the faith of Israel inspires and justifies the content of the concluding prayer, in which the lyrical subject of Ps 90 says on behalf of these people: "May the favour of the Lord our 
God rest upon us!" (v. 17). The first part of the diptych reveals a short time, and the poet encourages the believer and the people to recognize their "ephemerality" (vv. 3-10). At the same time, the majestic eternity of God and His enduring favour for the people, marked as a stronghold on a rock as opposed to the time of man (and of the people) that is only a short, irrevocably passing and "withering" moment, is for him the most important source of hope for salvation. The latter includes the transformation of the time of wrath into a time of grace "making God's eternity present," that is, into an experience of His goodness that is an essential dimension of God's eternity. The eternity of God in Ps 90 does not overwhelm man's "days" and "years," nor does it reduce them to zero. Still, it can transform them and thus give them a meaning, namely, a taste of the goodness of the eternally lasting God, unchanged in His favour for the believing Israelite and all the people of the Covenant. It shows the content of the prayers that make up the second diptych (vv. 13-16). Yet, the transition from the experience of the limited, fragile and transient nature of man's lifetime on earth to tasting God's eternal life will only be possible if the lyrical subject achieves "wisdom of the heart" through prayer (vv. 11-12). ${ }^{11}$

It is worth remembering that before the final editing of Ps 90, which gave this work its full harmony, there was first an original work comprised of vv. 2-12, as mentioned earlier, which described the experience of man as such. What is more, it is dominated by a vision of God appropriate to a non-Israelite. ${ }^{12}$ Verses 1:13-17 were added during the final editing in order to develop this general concept of a deity into an image of the God named JHWH (v. 13), with the typical

11 Jacques Trublet ("La poétique des psaumes," Lum Vie 202 [1991] 62) indicates the key importance of the above-mentioned vv. 11-12 as a revealing factor leading to a change in the poet's (praying man's) experiences and is a link between the two main panels of the psalm (vv. 3-10 and vv. 13-16) in his study of the poetics of the Psalms; in turn, Jean-Noel Aletti and J. Trublet in their work on the relationship between the poetics and theology of the psalms (Approche poétique et théologique des Psaumes. Analyse et Méthodes [Paris: Cerf 1983] 86) write that Ps 90 in its concentric structure perfectly reflects progress in the area of experiences: from the fear of indignation and God's anger (vv. 7-10) to an orientation towards His love and faithfulness (vv. 14-15). That is most evident in v. 7: the praying man experiences fear and anxiety about the devastating effects of God's anger on the present life of the people, but in vv. 14-15, he opens up to the joy and glory he expects from God very soon as something inevitable. That is indicated by the term "at dawn" (בבקר), which in several psalms refers to God's imminent and rapid readiness to respond in the form of a salvific intervention that brings help to the just (cf. Ps 46:5; 143:8).

12 Many scholars represent this view. It is enough to name a few: H.-P. Müller, "Der 90. Psalm. Ein Paradigma exegetischer Aufgaben," ZThK 81 (1984) 265-85; W.H. Schmidt, “"Der du die Menschen lassest sterben.' Exegetische Anmerkungen zu Ps 90," Was ist der Mensch...? Beiträge zur Anthropologie des Alten Testaments. Hans Walter Wolff zum 80.Geburtstag (eds. F. Crüsemann et al.) (München: Kaiser 1992) 115-30; E. Zenger, “"Dem vergänglichen Werk unserer Hände gib Du Bestand!' Ein theologisches Gespräch mit dem 90. Psalm," Die Verantwortung des Menschen für eine bewohnbare Weltin Christentum, Hinduismus und Buddhismus (eds. R. Panikkar - W. Strolz) (Herder: Freiburg im Breisgau - Basel - Wien 1985) 11-36. 
Israeli concept of the relationship between JHWH, the servants of JHWH and the phrase "our God" written into it. While vv. 1-12 mentions the life expectancy of many individuals, in vv. 13-17, the time perspective includes the days and years of generations of JHWH's "servants" (vv. 13,16) firmly established in history (misery - cf. vv. 13,15). ${ }^{13}$

\section{2. "Yesterday," "Our Days," and "Morning." Three Layers of Man's Time}

In the literary composition of Ps 90 presented above, one can discover a chronological line that links all three essential segments (vv. 3-6; 7-10; 13-16), which is yet another way to direct man's time towards God's eternity. Thus, in the aforementioned vv. 3-6, the author concentrates his attention on "yesterday that is gone" (v. 4b), and in vv. 7-10 on "our days" that "decline in Your fury" (v. 9a) and "quickly pass" (v. 10b; cf. v. 12a: "number our days"), in vv. 13-16 on the expected action of God in the"morning, that we may sing for joy and be glad all our days" (v. 14; in TM both verbs are in the imperfect). ${ }^{14}$

Some critics do not see anything extraordinary in such a presentation of man's time, and they even take it for granted. It is difficult to agree with them because what distinguishes God's revelation from human philosophies is the unveiling of the truth about these three phases, not so much successive ones, but the layers of man's time submerged in salvation history. Moreover, the future is an object of prayer or expectation, because it is seen as a time of God's intervention. In Ps 90, this future is linked with the expectation of experiencing (cf. "satisfy us!"- v. 14) the gift of "thy generous goodness" that will come from God, who is "from age to age."

In general, according to the author of this song, time is a reality which not only measures man's life "by days" and "by years," but which the believer experiences at every moment in three dimensions. These three dimension are the past (vv. 3-6), present (vv. 7-10) and future (vv. 13-16) that overlap and thus intensify

13 Cf. Zenger, "The God of Israel's Reign," 163-164. The author continues: "Verses 1 [lb] and 17 agree in the designation of God as 'Adonai-Ruler of all'; at the same time, v. 1 [lb] formulates the historical, generation-spanning experience that YHWHhas been shown to bea 'hiding-place/refuge"' (p. 164).

14 In Gesenius' Hebrew Grammar, published by E. Kautzch (second English edition), paragraph 107 of "Use of the Imperfect" writes about the meaning of the imperfectum in compound sentences: "In the sphere of future time. To express actions, etc., which are to be represented as about to take place, and as continuing a shorter or longer time in the future, or as being repeated" (no. 3). Many modern translations (IEP; CEI; TOB; from Polish: SNP) give future forms, others use modal forms: "so that we may enjoy" but clearly oriented towards the future, cf. BT. 
the human experience of the present time ("our days"). They enrich it with a dimension of memories reaching back to the work of creation (v. 3, cf. Gen 3:19; Ps 103:14; 104:29; 146:4; Job 1:9), giving hope that is connected in the Psalms with God's action in the "morning" (cf. Ps 5:3; 59:17; 63:1; 88:14; 130:6), and the motif of awakening after the night of death (Ps 16:10-11; 17:15; cf. 4:7; $11: 7 ; 16: 11)$.

Other psalmists in those times saw a similar three-dimensionality. However, being more open to Kohelet's concept of life and the strong physical concept of time, they do not see the two dimensions of memory and hope. Thus, we read in Ps 39:

Behold, Thou hast made my days a few handbreadths, and my lifetime is as nothing in thy sight.

Surely every man stands as a mere breath!

Surely man goes about as a shadow!

Surely for nought are they in turmoil;

man heaps up, and knows not who will gather! (vv. 5-6)

Man is aware that the past is like a slowly disappearing "shadow," the present is like "nothing" and the future is entirely unknown. Time configured in this way is an element which ultimately and significantly influences man and determines his life. The author of Ps 39:6 does not hesitate to state that time is everyone's "mere breath" even for a strong man (כל־הבלכל־אדם). It lasts a short time, and one generation follows another. ${ }^{15}$

\section{God's Eternity Is a Refuge for Man's Time (vv. 1-2:17)}

Already in the first verses (vv. 1-2), the poet speaks about God, who always "is" one and the same, and about people who pass by "from age to age." Is there any relationship between them? Does he show in verse 17 what this relationship should be like?

${ }^{1}$ Lord, You have been our refuge

from age to age.

15 The priestly tradition of the Pentateuch has taken up the entire vision of salvation history in the form of a genealogy (cf. Gen $2: 4 ; 5: 1 ; 6: 9 ; 10: 1 ; 11: 10.27 ; 25: 12.19 ; 31: 1.9 ; 37: 2$; Num 3:1). They express very vividly the truth about time as a reality flowing in the rapid succession of the generations that come and replace those that are gone. 
${ }^{2}$ Before the mountains were born

or You brought forth the earth and world

from everlasting to everlasting, You are God.

${ }^{17}$ May the favour of the Lord our God rest upon us!

Establish the work of our hands for us,

yes, establish the work of our hands!

The psalmist begins his meditation on man's time with the most important truth: God lasts forever and is unchangeable. JHWH is present before the world was created: "from everlasting to everlasting" (ומעולם ער־עולם). The noun עולם (used in the phrase מעולם ער-עולם (V. 2c) occurs several times in the OT without an article (Ps 103:17; 1 Chr 29:10; Jer 7:7; 25:5; Sir 39:20), but, similarly, it is preceded by a article several times (Ps 41:14; 106:48; Nah 9:5; 1 Chr 16:36; Dan 2:20). It means the time of God, which has neither beginning nor end, in our understanding meaning "eternity."16 It is not subject to any change or transformation. ${ }^{17}$ The parallel phrase בדר ודר (v. 1b) adds an important aspect to this divine eternity: being something other than man's time, it does not remain completely detached from it, from the life of subsequent generations of people. The God who continues in eternity is the God of every generation of people. ${ }^{18}$ Moreover, by referring to Deut 32:6-7, it is known that He is first and foremost the God of the next generation of the Covenantpeople, Israel. ${ }^{19}$

Therefore, at the very beginning of verse 1a, the psalmist compares God's eternity mentioned in $\mathrm{v} .1 \mathrm{~b}$ to a shelter on a high rock. It is like a tent, in which

16 Cf. E. Jenni, "Das Wort “olam im Alten Alten Testament," ZAW 64 (1952) 202.

17 "Il soit, et il est toujours la, invulnerable au temps, a l'inverse des humains" (J.-L. Vesco, Le Psautier de David. Traduit et commenté [Paris: Cerf 2006] II, 846).

18 This strong relationship of God, who is eternal, with the people engulfed in the disturbing history of Israel, is seen by Erich Zenger ("The God of Israel's Reign," 166): "Psalm 90, in its entirety, has a strikingly strong relationship with Deuteronomy 32. Probably even the secondary address to God that opens Psalm 90, 'you have been our dwelling place ...' (90:1 [lb]) alludes to the blessing of Moses in Deuteronomy 33 (cf. Deut 33:27; the connection can be seen in the NRSV marginal reading,'The eternal God is a dwelling place.'), which like Psalm 90 is ascribed to the (prophetic)'man of God'by its title. (...). The essentially unified'song of Moses' in Deuteronomy 32, whose origin during the exile or in the early post-exilic period still appears most plausible, is a'theodicy with a consolatory ending' (Karl Budde) which, just as the proem in vv. 1-3, brings out pedagogic wisdom whose 'teaching' is meant to confer on the addressees new life, strength, and consolation. Above all, the'song' has the intention of making Israel capable - precisely in the face of the catastrophic experiences of its history — of falling prostrate before YHWH alone as the king of the world (cf. Deut 32:43). Thus, in vv. 4-5, the theme proclaims the trustworthiness and righteousness of YHWH (YHWH is the saving 'rock'par excellence: this divine name, coming from Zion/Jerusalem theology, occurs seven times in Deuteronomy 32!) in contrast to the unfaithfulness/guilt of Israel."

19 Gerhard J. Botterweck ("dôr," TDOT III, 177) notes that the author of Deuteronomy 32:7 refers to those who represent Israel'searlier generations: Moses (Deut 7:9), Noah (Gen 9:12), Abraham (Gen 17:7-9; Ps 105:8; 1 Chr 16:15), David (Ps 89:5.4). 
the passing time of human generations has its anchor and support through prayer lifted from the earth. God's eternity is for people's time ("from age to age") a stable horizon or an unshakable reference point, more permanent than mountains. Generations change, one takes the place of another, but as the psalmist confesses: "You were our refuge" (v.1a); "You are God" (v. 2c).

This continuance is inscribed in the essence of God. In contrast, this passing away, the replacement of one people (generations) by other people, is the most characteristic feature of man's time, but in vv. 1-2 it is related to God's eternity. It contains the phenomenon of duration. Time is seen here by the inspired author as a path that runs before the face of God, that is, in the presence of the One who "IS" and exists "from age to age" (v. 1b; cf. Exod 3:14-15; 6:2; Isa 44:6). Although man, immersed in the current of time with the passing of successive generations, appears to the poet as a temporal being, he finds refuge in God who lasts "from everlasting to everlasting" (v. 2b). God's continuance or eternity rises even above the ancient time of origin, when the mountains, the earth, and the world of creatures appeared (v. $2 a){ }^{20}$

God, who "is" beyond the time of all creatures and people, appears to the psalmist as a "refuge" ( $m^{e}$ 'on - literally "accommodation" or "place of refuge") for people living in time, "from age to age." It saves those who seek refuge in it. The picture recalls texts in which the lives of people passing from generation to generation are like a rushing river:

I love you, LORD, my strength. The LORD is my rock, my fortress and my deliverer; my God is my rock, in whom I take refuge, my shield and the horn of my salvation, my stronghold. I called to the LORD, who is worthy of praise, and I have been saved from my enemies. The cords of death entangled me; the torrents of destruction overwhelmed me. The cords of the grave coiled around me; the snares of death confronted me. In my distress, I called to the LORD; I cried to my God for help. From his temple, he heard my voice; my cry came before him, into his ears (Ps 18:4-7; cf. 31:3; 32:7; 46:2; 71:3).

These thrilling and abruptly threatened short lifetimes of man are "waves of death and confusion carrying annihilation" that cause devastating forces to be generated by spoiled people: "Rescue me, O my God, out of the hand of the wicked, Out of the hand of the unrighteous and cruel man" (Ps 71:4).

God, who is "for us a refuge from age to age" (Ps 90:1) is the Lord of all generations, he is the God of all times, including the future: "And may the favour of the Lord our God be upon us!” (v. 17a). The jussivus used here (Iיהי) expresses

20 Verse 2, as Hans-Joachim Kraus writes in Psalmen (p. 798), is a testimony of "God's sovereign power over the world and the eternity of the God of Israel. In Proverbs 8:25, this is how God's Wisdom is shown"; Vesco, Le Psautier, 846. 
the fervent desire of the psalmist that God's favour or even friendly graciousness (נעם) be "over us" and subsequent generations. From this desire, which he considers to be true to "our God" in v. 17b, the psalmist raises a prayer to Him that $\mathrm{He}$ may continue to be a refuge for "us" and "our works": "And establish the work of our hands, yes, establish the work of our hands!" The same form of command mode used twice in this verse in the polel conjugation (with a strengthening heh in the first form) from the core כון indicates God's activity, which strengthens, giving a solid, lasting shape. ${ }^{21}$ It refers to the creation of man (Job 31:15) and the world (Ps 8:4; Ps 3:19; 2 Sam 7:24 concerning the people). Furthermore, it even refers to God who brings to life what has dried up: "You showered down abundant rain, God; when your inheritance grew weary, you restored it yourself" (Ps 68:10; see the theme of withering in Ps 90:6). ${ }^{22}$ Besides, the prayer in v. 17 expresses the expectation for the saving action of God JHWH ("I am"), which defines the very essence of Israel (cf. vv. 130:5-7).

God's continuance "from age to age" comprises the past, present, and future time, and this is done in an active way (v. 17). For believing Israelites, this means that He holds in His hands the past as well as the present and future time of all people. His continuance "from everlasting to everlasting" is not in any danger; it is beyond time. The Psalmist professes his faith in God, who "IS" the only refuge for man's passing through time. At the same time, he states that there is no time (generation) in which there is no God. ${ }^{23}$

21 Cf. HALOT, s.v. כון - polel conjugation: to set up to last, fix solidly: man Deut 32:6; Ps 7:10 119:73

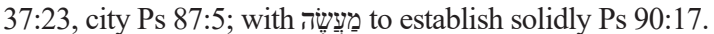

22 The same model of waiting for God's action, which is an answer to the prayer of believers (the righteous) and flows from the identity of JHWH, His lasting faithfulness to the people of the Covenant, is present in Ps 33: "Genau dieses Konzept wird auch in der Themenangabe Ps 33:4-5 präsentiert: V. 4 betont die Verlässlichkeit und Treue JHWHs und V. 5 hält fest, dass sich Gerechtigkeit und Recht JHWHs 'auf der Erde' als Liebe/Güte erweist, in der er sich, wie die beiden Abschnitte des Korpus V. 6-12 und V. 13-19 zeigen, vom Himmel her (vgl. V. 6a und V. 13a) 'seinem Volk' zuwendet (V. 12), als dessen Proprium in V. 18 das Warten/Hoffen auf JHWHs rettende Liebe/Güte genannt wird. (...). Ziel dieser Zuwendung des im Himmel thronenden Weltkönigs JHWH ist die Rettung 'seines Volkes' aus Tod und Hunger (Ps 33:19) - und zwar als Erweis jener hesed, von der die Erde zwar 'voll' ist (V. 5b), die aber nur denen zuteil wird, die darauf 'warten' (V. 19)." E. Zenger, "Es sei deine Liebe, JHWH, über uns! Beobachtungen zu Aufbau und Theologie von Psalm 33,"”Gerechtigeit Und Recht zu uben" (Gen 18,19). Studien zur altorientalischen und biblischen Rechtsgeschichte, Religionsgechichte Israels und zur Religionssoziologie, FS E. Otto (eds. R. Achenbach - M. Arneth) (Wiesbaden: Harrasowitz 2009) 360f.

23 Cf. Schmidt, "Der du die Menschen lassest sterben," 121. 


\section{Man's Time Has an End Set by God (vv. 3-6)}

God's eternity (mentioned in vv. 1-2,17), which exists beyond the passing of time (cf. Prov 8:25; Ps 65:7), contrasts with the short time of man's life. ${ }^{24}$ In fact, it is dramatically evoked in the above-mentioned vv. 3-6:

\footnotetext{
${ }^{3}$ You return man to dust, saying,

Return, o sons of mortals!

${ }^{4}$ For in Your sight a thousand years are

but a day that passes, or the watch of the night.

${ }^{5}$ You swept them away like a flood, they are like a dream;

they are like grass which is renewed in the morning:

${ }^{6}$ in the morning it flourishes and is renewed;

in the evening it fades and withers.
}

Time here achieves the features of a prison, common for all people and plants. Sirach sketches out the same vision of man's time: "Like dense leaves on a lush tree, one falls, and the other grows, so do the generations of flesh and blood, one dies, and the other is born" (Sir 14:18). The passing of time is so firmly inscribed in man's essence (nature) that it is in no way subject to his power. It is not man himself who decides when he "breaks away" from the lush tree of history like individual leaves from a tree and dies, nor when he is born and grows up. Man has no power over his time.

The shadow of death, commanded by God (v. 3), hovers over time that passes quickly and is beyond man's domination. In other words, man's time is limited, short, and at a specific, rather unknown moment, it definitely ends, but according to God's will. Not only does v. 3 say so, but this is also present in the image of the "watch of the night" (v. 4c), which, even if there are four, basically go away in some empty half-sleep, departing with the arrival of day. A similar meaning is given in the image of waking up in the morning from a night's "dream" (cf. v. 5). The time of man's life ends unexpectedly. However, it is not a kind of fate, but God himself, waking us up from a dream who decides about its end, not man. This "dream" lasts for a short time and ends in one moment, like a dream that awakens man. God's intervention, who is eternal, during man's time makes us look at things with hope, not with passive resignation, or even despair.

24 "Der »ewigen« Zeit Gottes steht die vergnägliche Zeit des Menschen gegenbüer - und zwar, so bklagt es der Anfang dieses Abschnitts, als vom Schpöfergott selbst immer wieder gewaltsam gesetzte Beendigung der individuellen Lebenszeit" (F.-L. Hossfeld - E. Zemger, Psalmen [Würzburg: Echter 2002] II 610). This is a reference to the concept by H.-J. Kraus: the time of man against the eternity of God. 
Nevertheless, even more so than in v. 4, there are other dramatic, almost tragic symbols of dried grass and a withered flower. ${ }^{25}$ They express the painful truth about man's time as a decisive factor in aging, even "withering." The influence of time on man is like that of the sun, due to which flowers and grass wither. These dramatic symbols of time are known in the sapiential tradition: "Man, who is born of a woman, is short of days and full of trouble. Like a flower he comes forth, then withers away; like a fleeting shadow, he does not endure" (Job 14:1-2); "All flesh is like grass and all its glory like the flowers of the field. The grass withers, the flower falls when the breath of the Lord blows on them; indeed, the people are grass. The grass withers and the flower falls, but the word of our God stands forever" (Isa 40:6-8; cf. Ps 102:12; 103:15-16; 129:6). As one can see, they express the most fundamental truth about man's time: even if it is relatively long, it has its irrevocable and indefinable end, preceded by the process of "withering" (cf. Matt 13:5-6). All of this is evidence of the insignificance and transience of time.

Man's time has an inevitable end. The symbols of awakening from sleep, withering grass and a withering flower in vv. 5-6 reveal the truth about the stage immediately preceding the end and point to it. ${ }^{26}$ Since the beginning of creation, the melancholic shadow of death hovers over man's time, as the poet expressed in verse 3, which opens the stanza and introduces these three symbols:

You return man to dust, saying,

"Return, o sons of mortals!"

The poet, though he uses the noun "dust" (דכא), refers to the beginning of man's "time," to his creation from the dust of the earth and judgment for the sin of rebellion against the Creator (cf. Gen 2:7; 3:19). ${ }^{27}$ The "end" of man's "time" is not primarily the result of the aging of the "mortal" body. The word of God and His irrevocable will expressed in the form of an imperative hover over the extended existence of the "sons of mortals." ${ }^{28}$ It is God who definitively ends man's time by giving the command to return to ashes (cf. Ps $103: 14 ; 104: 29 ; 146: 4$; Job $4: 19 ; 10: 9 ; 14: 1 ; 34: 14-15 ;$ Ecc 12:7). ${ }^{29}$

25 Cf. T. Tułodziecki, “"Dzisiaj kwiatem, jutro słomą' - tajemnica ludzkiego przemijania w Ps 90,” VV 24 (2014) 73-94.

26 T. Booij, "Psalm 90:5-6: Junction of Two Traditional Motifs," Bib 68 (1987) 393-396.

27 Cf. Ps 104:29; the noun used in v.3 דכא undoubtedly refers to Gen 3:19. This is supported by the fact that the hymns found in Qumran often speak of a return to dust, also using the vocabulary of Gen 3:19, and refer to death designated by God. Cf. $1 \mathrm{QH}^{\mathrm{a}} \mathrm{X}, 4.5 .12$; XII, 26.27 and others. They juxtapose dust with dust as in Gen 18:27 or Job 30:19; 42:6.

28 The bwv root word used by the poet in v. 3 occurs in the past tense of the undefined mode (hifil). It indicates that God's action on humans is stretched over time; in another place it is in a commanding form, which evokes God's decision to return man to the dust from which he was formed, and, figuratively speaking, "led out" (cf. Gen 3:19).

29 Some exegetes claim that the words in v. 3 refer to the creative decision (proimordial decision) of God to create people as mortals. It is by creating man that God decided that he must also die. This is 
The duration of man's time is subject to a command which can only come from God at any time. The terms דכא, בני־ארם , דנוש in v. 3 link man's time ("from dust") to the fact of creation, but at the same time indicate God's power over it. Man, on the other hand, has no such power, because he is weak. He cannot determine either the length of his time or the moment it ends. It is all done by God's will and not by any other factors. This excludes any pessimism, resignation, despair, or rebellion. On the contrary, it raises the psalmist's confidence in the Creator and inspires him to pray (cf. vv. 11-17). ${ }^{30}$

The "end" of man's time, irrevocably defined by God, determines that, even though he lives a certain number of days and years ("seventy" or "eighty"-v. 10), life passes, it goes away (cf. Jdt 1:9-11). Even if this time lasts for "a thousand years," it seems like "one day." 31 Time has its beginning and its end; it is a closed unit, a defined whole. It contains some sense, because all of time, even when counted in thousands of years, simply flows "in Your sight" (v. 4a). ${ }^{32}$ As such, the entirety rests on the axis of successive "days" and "years" on the timeline of the generations (vv. 1,2,4; cf. Job 7:7-8; 14:2; Eccl 7:28; Ps 102:3-11; 103:15-16; Isa 40:7-8; Deut 32:30; Hos 23:10).

An important conclusion can be drawn from the above analyses: it is God himself who determines man's time and decides if it is over quickly. Moreover, it ends with a dramatic return to ashes, preceded by a painful period of withering, since he was created from the dust of the earth as a mortal being.

also how Mesopotamian myths put it. Cf. Müller, "Der 90. Psalm,” 271; R. Clifford, Creation Accounts in the Ancient Near East and in the Bible (CBQMS 26; Washington, DC: Catholic Biblical Association 1994) 146-147.

30 Cf. Abelava, Le Psaume 90,1 46f.; The positive aspect of God's command "return!" (v. 3), understood as an invitation, is convincingly justified by T. Tułodziecki when writing: "When the Lord calls out to the fragile human being to 'return,' it is from the mouth of the Psalmist (Ps 90:3) that he wants to persuade him to recognize the Lord as the truly life-giving source. The word 'return' in Psalm 90:3 is the Lord's only expression in the entire psalm. Although it is in the imperative, it must be understood as a word of invitation. God, who cannot be placed within the time frame of the human world, reveals Himself by saying 'return.' If we are of God, created in His image (Gen 1:27), it means that our homeland and 'escape' is indeed in Him" ("Dzisiaj kwiatem, jutro słomą," 82-83).

31 Cf. Auffret, "Essai sur la structure littéraire," 262-276, 272.

32 It is difficult to agree with the commentator (Hossfeld - Zenger, Psalmen, 610) who sees nothing positive in the aftermath of generations, because in vv. 3-4 it is said that "vom Gehn und Kommen der Menschengeschlechlechter die Rede ist, was aber nicht positiv, sondern negativ beurteilt, in enn man die dadurch atomisierten Einzelleben mit der bleibenden, unendlichen Lebensfülle Gottes confrontiert" (V 4). The authors' reference to the commentary in chapter 3 about the act of grinding man down to ashes (without biblical references) rather than to Gen 2:7 and 3:19 is not justified. The motif of a "contrite" spirit and heart and "crushed bones" present in Ps 51:10.19 (ashes), which God does not despise, makes the image in v. 3 (man returning to the dust of the earth) to seem as something that ultimately has a deeper and positive meaning precisely in the "eyes" of God, who "is from age to age" (v. 2). 


\title{
5. Man's Time Under the Sign of God's "Wrath:" "Hardship and Vanity" (vv. 7-10)
}

The author of Ps 90 refers to the biblical thesis about limiting the years of a man's life because of sins, an idea already found in Gen 6:3. In his work, he confesses:

\author{
${ }^{7}$ For we are consumed by Your anger, \\ and terrified by Your wrath. \\ ${ }^{8}$ You have set out iniquities before You, \\ our secret sins in the light of Your countenance. \\ ${ }^{9}$ For all our days pass away under Your wrath; \\ we finish our years like a sigh. \\ ${ }^{10}$ The length of our years is seventy years \\ or eighty if we are strong; \\ yet their pride is but labour and sorrow, \\ for they quickly pass and we fly away (vv. 7-10).
}

Thus, man's time is significantly influenced by God's "anger" (א) and "indignation" (חמה), which are recalled in this passage at the beginning in v. 7 and repeated in v. 11. They "destroy" (כלה) and "disturb" us (בהל) (בהל).

The noun "anger" used by the poet (א) comes from the root word, which means "to be hot." The author wants to say that God's wrath is similar to the oriental sun, which continually emits hot rays at plants and causes their vegetation to be strongly threatened, basically destroyed, making them disappear. Just as the hot sun not only dries the grass but its heat also burns it, so too God's wrath "destroys us" and slowly removes us from the face of the earth (cf. Ps 37:20; $39: 11 ; 71: 13$ ). Using the verb (כלה) in v. 7, the poet alludes to the destruction that man suffers because of the misfortunes which occur during his lifetime and are understood as God's punishment for his sins. ${ }^{33}$ The Psalmist probably first has before his eyes the tragic events of the fall of Jerusalem and Israel, and then the position of the community (hence plural "we" in v. 7) in exile, removed from their land since they have been affected by God's wrath after their sins.

A man's heart, aware of the very serious consequences of God's wrath burning like a hot sun, suddenly fills with fear: "We are consumed by Your anger and terrified by Your wrath" (v. 7b). Here, the poet uses the verb from the root

33 God's wrath, for example, in $1 \mathrm{Mac}$, can be seen as "a metaphor (of anthropomorphic character) for God's great agitation, which was the result of great iniquities committed by the chosen people. We must keep in mind the fact that, as shown above, based on the parallelism of the texts of verse 1 Mac 2:49bc, God's wrath must be equated with punishment." G. Baran, "Gniew Boży a gniew ludzki w świetle terminologii Pierwszej i Drugiej Księgi Machabejskiej,” VV 33 (2018) 68-75. 
work בהל, which even occurs twice in Ps 6:3-4: "My bones are in agony, my soul is deeply distressed." This fear is not only an inner, spiritual experience, but can also be felt in the body ("bones") that is experiencing shock. The same thing happens in nature when God covers His serene face: "When You hide Your face, they panic; when You take their breath away, they die and return to dust" (Ps 104:29). Such panic, in fact, means the fear of disappearing and decaying. Thus, man's time is marked by the fear of it coming to an end. Nevertheless, a believer, even in such permanent danger, cries out to God with the hope of salvation: "My flesh and my heart may fail, but God is the strength of my heart and my portion forever" (Ps 73:26). ${ }^{34}$

The cause of God's "wrath" and "indignation" that so strongly influences man's time that it becomes a time of stress and fear, and even of slow disappearance, are sins and guilt (v. 8). God knows all our sins. They are always before Him as if written on a tablet or a scroll: "Hide Your face from my sins and blow out all my iniquities!" (Ps 51:11; cf. Isa 65:6; Jer 2:22). They are constantly before Him (cf. Ps 51:7). Yet, the light of His face shines through even the most "hidden sins" (v. 8b), those furthest in time, and those that man hides from himself even under the shield of oblivion, pride, lack of discernment or self-defence (cf. Ps 19:13; 31:7; 44:22; 51:3-7; 67:2; 80:4; 89:16). The extraordinary light of God's face usually carries a blessing (cf. Ps 80:4; 89:16; 67:2; Num 6:24-26). However, according to the author of Ps 90:8, it directs its light at all of man's iniquities, his grave sins and crimes, revealing the whole drama of his life. All is completely unveiled before God. This light, which brings man's sins out of the hidden darkness, together with God's ardent wrath, burdens man's time, making it flow quickly and loseits calm stability, thus becoming a time of rapid flight, full of fear, carrying a curse instead of a blessing.

In turn, the noun הגה used in v. 9, understood as a "sigh," combined with the verb הגה encourages thinking about the shortness of breath in a man who is approaching death (cf. Ps 31:3; 78:33). These are not emotionally neutral sighs, but full of moaning and pain (cf. Ez 2:10). Man's time, influenced by the action of "anger" and "indignation" on the part of God, becomes like the time of pre-mortal weakness, marked by suffering and sorrow. He is in danger of breaking his bond with God, which has been dramatically weakened by sins. That is why this time becomes negligible, as if it were empty, meaningless, ephemeral (cf. Ps 39:5), similar to a canvas eaten up by moths (Ps 39:12). ${ }^{35}$

34 Frank-Lothar Hossfeld and Erich Zenger (Psalmen, 611) are not right when writing a thesis about Ps 90:7-10 that is rather characteristic of the philosophy of despair that "angesichts des Zorneshandelns Gottes diese so kurze, vergängliche Lebenszeit eigentlich kein Leben ist."

35 Cf. Schmidt, "Der Du die Menschen lässest sterben," 130; Jean-Luc Vesco (Le Psautier, 849) cites the translation of LXX Sirach that reads the Hebrew root word הגה by resembling the Syrian word for spider, which weaves its network with all its commitment and strength, but it is ultimately not 
Man's time, burdened by God's "wrath," even though it is full of activity, ultimately turns out to be "hardship and futility":

The length of our years is seventy years or eighty if we are strong;

yet their pride is but labour and sorrow, for they quickly pass and we fly away (v. 10).

From the analysis of man's lifetime in the existential and theological dimensions carried out in vv. 3-6 and vv. 7-9 mentioned above, the author of Ps 90 moves on to statements related to the observation of its length counted in years. He precisely states that it is 70 years on average, and in the case of exceptionally strong people, 80 years. In antiquity, the subject of the length of life was often taken up by philosophers and ethicists. Some Egyptian texts limit this time to "60 years, which Thot grants to pious people." ${ }^{36}$ There is also the text of Ptah-Hotep's Wisdom, which extends the life of a just man to 110 years. However, there is a noteworthy fundamental truth written in the Hymn to Aton which states that "the time of life is counted." ${ }^{37}$ In the world of Greek culture, some expressions are very similar to those of Ps 90:9. For example, Solon states: "A man has 70 years to complete the course of life ... and nothing else meets him but misfortune." ${ }^{\prime 38}$ Nevertheless, the same Solon, writing to the poet Mimnermus, asks him not to want to die at 60 . On the contrary, he encourages him to change his mind and to want to live until he is $80 .{ }^{39}$

The Book of Genesis (6:1-4) deals with the length of man's life on earth and sets an upper limit of 120 years (v. 3). This is a drastic reduction in the "astronomical" longevity referred to in Gen 5. It is related to sin. According to this rule, Moses only lived 120 years (cf. Deut 34:7), while a much longer life span (130 years) is attributed to Jacob (47:8-9). Yet, Caleb, according to the Book of Joshua, lived only 85 years (Josh 14:10), and Joshua himself lived 110 years (Judg 2:8). It is easy to see that in the OT books mentioned here, man's life expectancy is severely connected with justice. The old age of these figures is also cited as the time of happiness in contrast to Ps 90:10. It should be added that the length of a man's life, given as a norm by the Psalmist, is correlated with the principle of retribution in the Book of Jubilees: "The life span of ancient people was very long, up to a thousand years, and yet it was a wonderful time. Now, in our times, man lives a maximum of 70 years, and when he is healthy, 80 , and

permanent. Cf. A.A. Macintosh, “The Spider in the Septuagint Version of Psalm XC.9," JTS 23 (1972) 113-117.

36 Cf. G. Castellino, Libro dei Salmi (Torino: Marietti 1955) 346.

$37 \quad$ ANET, 370.

38 Herodot, Historie, I, 30ff.

39 Herodot, Historie, I, 22-23. 
everything is terrible." ${ }^{40}$ Thereby, the Book of Jubilees, dating from the second century B.C., contains an extremely firm commentary on the words of Ps 90 , pointing out that even a maximum lifespan does not mean happiness. All these 80 years are a series of misfortunes.

Concerning the previously mentioned texts, the author of Ps 90 in v. $10 \mathrm{~b}$ defines the quality of a man's lifetime. The form רהבם (hapax) he uses most probably comes from the root word, which means "to be anxious, to push, to worry." 41 Although some people interpret this form as "pride" or "honour," yet because of the context and semantics, it is more logical to translate it as "busyness, anxiety." By adopting this version, we can say that the psalmist speaks emphatically not only of the fact that man's life span is short, but also full of struggles and anxiety, which ultimately turn out to be עמל - "effort," "fatigue," or "anxiety," and also - "futility," "being deceptive and empty" since they are marked by iniquity or idolatry. ${ }^{42}$

The period of 70 or 80 years in itself is a kind of illusion followed by disappointment. With the help of these two nouns, which often occur in pairs in texts of a sapiential character (cf. Ps 7:15; 10:7; 55:11; Isa 59:4; Job 5:6; 15:35; Ha 1:3), the poet reveals its pessimistic dimension. The noun which is particularly frequent in the Book of Kohelet, mainly shows man's lifetime as a period of punishment (cf. Ps 73:5), in which there is frustration due to the negligible results achieved over time. It has no positive effect other than poverty and misery (cf. Ps 7:15.17; 10:7.14; 25:18; 55:11; 107:12). Besides, this time "passes quickly" (גז חיש), ${ }^{43}$ and the people immersed in it, like birds, "fly away," as indicated by the verb used here (עוך) (cf. Deut 4:17; Na 3:16). In several texts (Hos 9:11; Job 20:8 and Prov 23:5), this means a disappearance that does not assume a return. ${ }^{44}$

The image of birds flying away is another very evocative in its truthfulness symbol of the "end" of man's time, over which God's wrath weighs down. It is not only limited and short, but full of hardships, which do not bring any lasting fruit. In fact, it is a movement which, year after year, is comparable to a one-way flight of great effort and exertion and full of dangers and fears (cf. Job 9:25-28).

40 Ksiega Jubileuszy [The Book of Jubilees], 23,15.

41 Cf. Ravasi, Il Libro dei Salmi, 890; it is not necessary to refer to the translation from TM to LXX and Peszitta, which see rubbam here (from rub - "to be numerous"), followed by most modern translations when reading: "most of them"- of those 70 or 80 years.

42 Both nouns often occur together (Ps 7:15; 10:7; 55:11; Isa 59:4; Job 5:6; 15:35; Hab 1:3). As J.-L. Vesco notes in Le Psautier, 850: "Les deux apportent la deception (Jb 15:35; Ps 10:7; 36:3-4; Isa 59:4). Le v. 10 du Ps 90 rejoint les reflexions de Qohelet (Qo 2, 23)."

43 Most exegetes change the perfectum form expressed in third person singular (זג) into third person plural form. They then connect it with the noun "years," which "quickly pass by."

44 Cf. R. J. Clifford, "Psalm 90. Wisdom Meditation or Communal Lament?," The Book of Psalms. Composition and Reception (eds. P.W. Flint - P.D. Miller) (Leiden: Brill 2005) 200. 


\section{The Prayer for a "Wise Heart" as a Key Point on Man's Timeline (vv. 11-12)}

In verse 11, which together with v. 12 serves as a link between the first (vv. 3-10) and second (vv. 13-16) parts of Ps 90, the poet asks a rhetorical question:

Who knows the power of Your anger,

and thy wrath according to the fear You are due?

There is no man who, by his own strength, can penetrate the mystery of how God's wrath works due to man's sins on the long line of his lifetime. ${ }^{45}$ No one can face either his destructive power to stop it, nor is anyone able to transform its character from devastating to saving. No one is able to "know" with their mind (v. 11a), that is, to "experience" and "endure," to "withstand" the power of God's wrath and indignation, and even more so to penetrate the meanders of his actions in a short and transient time (cf. Ps 78:49-51; Isa 13:9). No person, even the one who lives in the fear of God (cf. V. 11b), is able to understand what decisive role in a sinner's fleeting time is played by God's indignation hanging over him, as evidenced by the contents of the lamentation (vv. 3-10).

The only reasonable solution for a man who believes in the God Yahweh and recognizes at the same time all the "vanity" of his time marked by God's wrath due to his sins is to pray for His restraint. Verse 11 is only its beginning, and its full content is contained in Ps 85:

You withheld all Your fury, You turned from Your burning anger. Restore us, O God of our salvation, and put away Your displeasure toward us! Will You be angry with us forever? Will You extend Your anger to all generations? Will You not revive us again, that Your people may rejoice in You? Show us Your loving devotion, O LORD, and grant us Your salvation! (vv. 4-8).

The second part of this prayer is a request for the gift of wisdom: "So teach us to number our days that we may get a heart of wisdom" (v. 12).

Using as many as two verbs in this verse (ידע מנה - "to number, count" and "to know, teach"), the Psalmist points out how God's teaching is necessary for a man who discovers the insignificance of his time (cf. Prov 8:17; Ps 104:29-30). Only God is the Lord of man's time, and only He can reveal to man his unknown dimensions, factors, and references. Above all, a man who knows about death (cf. vv. 3-6) and hardship (vv. 7-10) should be able to appreciate every day as a gift of the good Creator, and be fully amazed, while seeing it as a new chal-

45 Cf. H. Witczyk, “Gniew Boga jak gniew człowieka?,” VV 33 (2018) 7-18. 
lenge. It is not a matter of prolonging one's life, nor of experiencing pleasure as in Kohelet (Ecc 2:24; 3:12nn; 5:17-19; 9:7-9; 11:9), nor of creative intervention. The Psalmist prays for the gift of accepting the time of life as it is, including the reality of death. ${ }^{46}$

The Psalmist prays that God will teach him and his community ("us") to count the days in such a way that they will find in them a guiding theme for connecting different events and even conflict situations (cf. Gen 3:16; Num 23:20). Kohelet possesses this skill since he can distinguish his days according to what he experiences in them (cf. 2:24; 3:1-10.12; 5:17-19; 9:7-9). However, Ps 90:12 is also about something more: meditating on man's "days" (cf. vv. 5-6, 9-10,12) in such a way as to accept not only what they are like (cf. 3-10), but above all what they really are. ${ }^{47} \mathrm{After}$ all, man's "days," meaning man's time, are nevertheless a gift from God! Only He knows their full value and all of their dimensions, and can, therefore, reveal them to the praying man when He teaches him to "number" them and to discover that they are given to him (as when Kohelet "counts" time, cf. $3: 1-10.13){ }^{48}$

The Psalmist is certain that the God he called upon will become the Teacher of the community and will reveal to it the secrets of the operation of his anger and, at the same time, of the meaning of time flowing under the sign of $\sin$ (in v. 12a he even uses the root word ידע in the hifil conjugation in the imperative form).$^{49} \mathrm{He}$ refers directly to the question from v. 11a (expressed with the same root word). In response to the question"who will know?" (v. 11a), he answers: "One who God will let know, whom He will 'teach"” (v. 12a).

In order for a man to correctly count the days of his life, to discover its meaning at all three levels (past - present - future), he should receive an appropriate measure, which can only be a "heart of wisdom." When God begins to teach man, a sinner, he can "achieve" these levels, even "receive" them (נבא second person plural in the hifil conjugation from the root word בוא - literally: bring, introduce, like for example, grain into the granary in 2 Sam 9:10). In other words, God can give a man an incredibly precious gift, which is such a "heart of wisdom" that has a share in God's wisdom and is thus able to recognize and understand God's actions in man's lifetime, including those inspired by his anger and indignation towards man's sins (cf. vv. 7-11) and, above all, God's call: "Return! O sons of mortals!" (v. 3b).

46 Cf. Ch. Forster, Begrenztes Lebenals Herausforderung. Das Vergänglichkeitsmotiv in weisheitlichen Psalmen (Zürich: Pano 2000) 191.

47 The ability to say "yes" to what time, days, and years bring, and to experience this "yes" among the many factors that negate its positive value. Cf. Hossfeld - Zenger, Psalmen, 612.

48 Cf. Abelava, Le Psaume, 160.

49 It is worth noting that seven imperative forms appear in the above mentioned vv. 12-17, and the first one is in v. 12a (from the core of ידע). 
To discover the most profound dimension of man's time in all its limitations, even "wisdom of the heart" is not enough (as in many OT prayers), but "a heart of wisdom" is needed. It is the most important organ of cognition wholly transformed by God. The purely rationalistic ability, let alone a hedonistic-utilitarian approach, in the search for some earthly and temporal meaning is not enough. Only a "new heart," which only God can "create" in man (cf. Ps 51:12-14), is capable of discovering God's plan for his earthly time and accept the wisdom that comes from God. It allows, in a spirit of trust in the Creator, accepting the end (limit) as part of God's plan: "Surely, You desire truth in the inmost being, You teach me wisdom in the inmost place" (Ps 51:8). ${ }^{50}$ Thanks to the wisdom which comes from God and which is recognized by a "heart of wisdom," man can understand and accept his short and transient, almost negligible, full of effort and futility fleeting time, and himself as a being immersed in it. The "heart of wisdom" that first assimilates God's wisdom and inspires his trusting prayer (vv. 13-16) creates the necessary conditions for God to enter with His "eternity" into man's time, which is threatened by death and additionally burdened and limited by sin. The "heart of wisdom" will also be able to ask God to "know," that is, to experience His "eternity" already during this fleeting and insignificant time. ${ }^{51}$

The analysis of the above-mentioned vv. 11-12 demonstrates how prayer opens this time for man, which is limited and threatened by God's wrath, a negligible and fleeting time (vv. 3-10) to the action of God, who is "from age to age." Thanks to Him, although this time does not extend mathematically, it takes on new dimensions: every day is known as a gift and a mystery (truth) coming from the Creator, recognizable only by those possessing a "heart of wisdom."

\section{Divine Elements Introducing “Eternity" into Man's Time: Mercy, Steadfast Love, Presence and Majesty (vv. 13-16)}

A "heart of wisdom" can lead a man, living in fleeting and insignificant times, to seek refuge and peace in God due to his sins and God's wrath (cf. v. 1). Hence the poet cries out:

Return, O Lord, how long will it be?

Be merciful on Your servants! (v. 13).

\footnotetext{
50 This important act of God ("teach me") is described by the Psalmist with the help of the hifil conjugation: "make me know the secrets of wisdom, the hidden truth, that is, the truth known only to You."

51 Cf. H.M. Wahl, "Psalm 90, 12. Text, Tradition und Interpretation," ZAW 106 (1994) 118-120.
} 
Verses 13-16 contain an answer to the meditation on time (vv. 3-10), beginning with a characteristic appeal that opens a fervent prayer to God, who is "from age to age" (v. 2). ${ }^{52}$ The phrase "how long" (ער־מתי) is not only a meaningful allusion to a long period of time overshadowed by God's "wrath" (vv. 3-10), but above all, a sign of fervent prayer for salvific intervention. That is what the two verbs used in the synonymous parallelism in v. 13ab speak of: a "return" (cf. "go back" in v. 3; שוב) (נחם). This prayer is not brought on by an unspecified lyrical subject, as mentioned in vv. 3-10, but the "servants" of God. As a result of the physically exhausting experience of insignificance and the passing of time, this subject discovers his identity: we are "your servants." Moreover, it is as servants that they first ask God to put an end to their anger ("be merciful!"). The verb used in this prayer expresses the truth about God's first and unshakeable love for His "servants," which, in the dramatic experience of man's time, must reveal itself as a concrete act of forgiveness for the guilt that lies within them, of the forgiveness of their sins and, therefore, of putting an end to their anger: "Turn from Your fierce anger and relent from doing harm to Your people" (Exod 32:12), that is, come back to us with your serene face of the God of the Covenant.

God's "mercy" is not so much fleeting compassion or consolation, but closeness and great, heartfelt concern to ensure that the evil caused by sins does not ultimately triumph over life, ending man's time prematurely. Such a "reversal" of God's wrath, through the "return" of a close God and the "mercy" shown to his "servants" can overcome the "futility" of their time, and even its primary cause, which is $\sin$ (cf. Deut 32:36; Ps 135:14; Isa 40:1). The history of Israel is the essential proof of this for the Psalmists. ${ }^{54}$

52 God is fulfilling these requests, as the next two works of the 4 Book of Psalter say: Ps 91 the promise of long life and salvation; Ps 92 - thanksgiving for these divine gifts. Together with Ps 90 they constitute a compact beginning of this collection and as such they are all closely connected. Cf. Hossfeld - Zenger, Die Psalmen, II, 497.

53 "Return" (literally "convert" to your love), this is a bold call to God: "Il doit revenir de l'ardeur de sa colère, se raviser, changer d'avis et se montrer bienveillant (Ex 32,12,14; Am 7,1-3,6; Jer 18 8.10; Jon 3,9-10). Moïse, comme le psalmiste, le lui demandait (Ex 32, 12-13), Dieu doit se laisser fléchir (Ps 106,45)" (Vesco, Le Psautier, 852).

54 The dramaturgy of the time of a man who has been touched by "God's wrath" is perhaps most strongly shown in 1-2 Kings. The motive of "God's wrath" is key to understanding the tragic end of Israel and Judah. In telling the story of the fate of the post-Davidic monarchy, the biblical author shows how YHWH's anger leads first to the division of the kingdom of Solomon (1 Kings 11:9-13), then to the fall of the Northern Kingdom (2 Kgs 17:5-23), and finally to the fall of Jerusalem and Judah ( 2 Kgs 24-25). According to the author of 1-2 Kings, there is an inseparable link between YHWH's anger and the unfaithfulness of his covenant according to the logic of the principle of retribution. In this way, the author of the Books of Kings interprets the tragic end of the monarchy in Israel and Judah as the result of the rightful agitation of YHWH in reaction to the sin of idolatry and its abandonment by the people. This theological vision of history is a lesson and a warning for future generations meditating on their times. Cf. K. Kinowski, "Motyw 'gniewu Bożego' w historiografii Ksiąg Królewskich," VV 34 (2018) 37-66. 
The call to "return!" (v.13a) is decisive since it corresponds, based on the principle of antithetical parallelism, to the act of a man "returning" to ashes, one who lives for a short time (v. 3). This "return" of God with mercy to man, a sinner, cancels his "returning" to dust. It means God's great commitment to come closer to His active, blessing presence, and he calls him by name - יהוה (v. 13a; cf. Ps 60:3.9.14; Jer 31:17-19). This introduces such an important factor as the memory of God's active presence in the life of His "servants" 55 to the dramatic experience of time. Turning to a close God whose goodness was known to the "fathers" (like God's "servant" Moses), the poet (a praying man) expresses an important truth about his time: although the present is full of painful thoughts and experiences (vv. 3-10), it remains in connection with the past, with the time of the great "servants." In this way, it relativizes the pain and suffering of its time, which seemed to be something impossible. ${ }^{56}$

Prayer that evokes God's closeness in the past opens up new possibilities for experiencing a passing, short, and destructive time. Indeed, this time even demands another response than "anger" from God, a response from His "eternity," which the Psalmist in v. 2 described with the words: "from age to age, You are." The poet calls it "mercy"; in fact, it is a mercy that removes the "anger" hovering over time due to sins and guilt (cf. v. 8). The answer to this prayer comes from God and is written into Ps 91, which forms a compact literary and theological whole with Ps 90:

Because he loves Me, I will deliver him; because he knows My name, I will protect him. When he calls out to Me, I will answer him; I will be with him in trouble, I will deliver and honour. With a long life, I will satisfy him and show him My salvation (vv. 14-16). ${ }^{57}$

In the following verses of his prayer to God, the poet refers to three more different actions by God who, "returning" and "being merciful" (v. 13), entered into man's time once again with His presence. The first of these is the generous goodness which God's "servants" (v. 13) are given:

Saturate us in the morning with Your steadfast love,

that we may sing for joy and be glad all our days (v. 14).

55 It is the name of the God of Moses and Israel, inextricably linked to His interventions in the history of the people. Cf. Hossfeld - Zenger, Psalms, 423.

56 Cf. Abelava, Le Psaume 90, 167.

57 As F.-L. Hossfeld - E. Zenger (Psalms, 613) emphasize that Ps 91 contains a double answer, a promise from God to the prayer expressed in Ps 90:13 by a single person (in the title identified with Moses). God speaks directly, using the form "you" to describe an Israeli who trusts Him (cf. v. 2). "Ps 91 kulminiert sodann in der als direkte Gottesrede gestalteten Zusage eines langen Lebens und eines von JHWH geschenkten Heils. Dass diese Zusage kein leeres Wort ist, sondern sich an dem erfüllt, der sich ihr überlässt, wird in dem folgenden Dankpsalm 92 betont" (p. 613). 
The noun "steadfast love" ( - v. 14a) is a kind of slogan in the Book of Psalms and means first of all a "generous goodness" of God manifested toward His Covenant people. It recalls various forms of God's goodness, manifested in His countless gifts. The verb "saturate" occurs relatively often in the Psalter. ${ }^{58}$ In almost half of the biblical and non-biblical texts in which it appears, it refers to the satisfaction of external, material, and bodily needs: "They asked for and brought quails, and saturated them with bread from heaven" (Ps 105:40; cf. 107:9; Lam 3:15; cf. the inscriptions of Karatepe and Sapphire - KAI no. 26, I,6; II,7.13.16; III,7.9; no. 222, A 22-23). However, just as often, the subject of human hunger and thirst are the internal, spiritual goods that are experienced in the temple: "May we be filled with the goods of your house, the holiness of your tabernacle!" (Ps 65:5). Those "goods" come from God to renew man's time: "He saturates your days with goods, your youth is renewed like an eagle" (Ps 103:5). In fact, all these goods come directly from God: "Naftali is saturated by grace, full of the Lord's blessings, the sea and the south will possess" (Deut 33:23).

Man feels hunger for material and spiritual goods because they determine that he does not have to experience a "waste" of time but can enjoy a higher, utterly different dimension of his time, which Ps 103 calls "youth" (freedom, creativity). The most crucial good that man needs every day, like bread, is חס - God's "steadfast love." As the author of Ps 63:3-5 writes: "Indeed, your steadfast love is better than life, my lips will glorify you. So I will bless You as long as I live; I will lift up my hands and call on your name. My soul feasted as with marrow and fat, my lips will cry out joyfully, and my lips will praise You."

"Steadfast love" here means God's faithfulness to the Covenant and the resulting generous goodness, the ray of His love. Through it, "all our days" become not only a time of freedom but above all a time of joy and cheerfulness. Thus, the passing of time can be completed by God within a new dimension, which is the experience of His "steadfast love" (חסד). It happens when He responds with the gift of His faithful and generous love to the prayer of a man immersed in his "days" and "years" of misery. This takes the praying may above the rushing current of the days and nights that follow and are marked by sin and God's wrath: "For His anger is fleeting, but His favour lasts a lifetime. Weeping may stay the night, but joy comes in the morning" (Ps 30:6; cf. 143:8). God's faithful love "saturates" man's time with the experience of longevity, which, like youth, is the experience of something of God's "eternity." The author of Ps 92 states so, and it forms the triptych with Ps 90 and 91: "Planted in the house of the Lord, they will flourish

58 It appears in the following psalms $(17: 15 ; 22: 27 ; 37: 19 ; 63: 6 ; 65: 5 ; 78: 29 ; 81: 17 ; 91: 16 ; 103: 5$; 104:13.16; 107:9; 132:15; 145:16; 147:14). Cf. G. Gerlemann, “sb'-saziarsi," Dizionario Teologico dell'Antico Testamento (eds. E. Jenni - C. Wsetermann) (Torino: Matietti 1982) 738-741. 
in the courts of our God. In the old age, they will still bear fruit, healthy and green they will remain, to proclaim "the Lord is upright, He is my rock" (vv. 14-16). ${ }^{59}$

This experience of "eternity" takes place in the "morning." The poet no longer refers to the beginning of the day as a process of passing away (as in v. 5). The "morning" is a symbol of a new dimension of time, a time filled with the presence of God, who returns to the praying man (people - cf. Isa 26:9) who seeks Him. The noun "morning" used several times signifies the time of God's intervention in the OT (cf. Exod 14:27; $2 \mathrm{Kgs} \mathrm{19:35;} \mathrm{Isa} \mathrm{37:36;} \mathrm{Job} \mathrm{10:9-11).} \mathrm{It} \mathrm{is} \mathrm{an} \mathrm{answer}$ to the prayer of his "servants." In Ps 90:14, it recalls the power of God, allusively compared to the power of the rising sun. The power of "steadfast love" (חסד) means that God "permeates" and "saturates" not only a negligible passing of time with His eternity. It also reveals His power at the end of man's "days" and "years" in a completely different way than the burning sun. It will ultimately prevail over the darkness of death and over death itself (cf. Gen 1:5b; Song 8:5) ${ }^{60}$

Another factor that brings the experience of "eternity" into man's passing time is the joy with which God fills the hearts of His "servants":

Make us glad for as many days as You have afflicted us,

For as many years as we have seen evil (v. 15).

The request for joy, expressed in a very firm tone (שמחנו), refers to the rich meaning of the root word שמה, which occurs 269 times in the OT. Most probably, this gift of joy is connected to the light beaming from God's face or from the Law, which the Lord's "servants" are ready to consider: "The precepts of the Lord are right, bringing joy to the heart. Commandments of the Lord are radiant, giving light to the eyes" (Ps 19:9: cf. Ps 13:9; 15:39; Sir 31:20). An equally important source of joy, which fills the hearts of believers, is God's work accomplished in their history: "For You, O Lord, have made me glad by Your deeds, I sing for joy at the works of Your hands" (Ps 92:5). In both cases, it is a matter of experiencing the joy manifested in man's external image.$^{61}$ In response, the poet expects from God, who continues in His "eternity," the experience of joy which will almost eliminate "days" and "years" of misery. Thus, this new dimension of time ("joy" coming from God) will become the dominant one and will prevail over the days marked by punishment for sins.

59 "The sequence of the three psalms according to the scheme lament - word of encouragement from God-thanksgiving is underscored by common and related motifs" (Zenger, "The God of Israel's Reign," 167).

60 Cf. Hossfeld - Zenger, Psalms, 423.

61 Cf. E. Ruprecht, "שמחה - rallegrarsi," Dizionario Teologico dell'Antico Testamento (eds. E. Jenni C. Wsetermann) (Torino: Marietti 1982) 742. 
Such "joy" seems to replace the time of a man burdened with guilt who has already passed away. It takes on the characteristics of something lasting, perfect, and guaranteeing happiness. That is why the prophet even speaks of the "eternal joy" that will be shared by the people previously crushed during the time of God's punishment and wrath (cf. Isa 61:7). However, this does not happen automatically, since it is God's answer to the prayer of His "servants." Both the first (v. 14) and the second (v. 15) request are addressed directly to Him. It is He who ultimately determines the quality of man's time: whether it is a time of painful and sad passing under the weight of sins, or whether it is a time "saturated" with His "mercy" and filled ("give!") with His "joy"- man's time, but already bearing the signs of God's "eternity."

The third action of God that gives a new dimension to the time of passing is to see God's majesty, which manifests itself in His works accomplished for His "servants":

Let Your work be manifest to Your servants,

and Your glorious power to their children! (v. 16).

The verb ראה used in this verse (in niphal conjugation: "be manifest," "be seen") brings to mind "seeing" and "watching" typical of theophanic manifestation, as indicated by the noun - "דזר - "majesty," "glorious power" reflected in spectacular extraordinary manifestations of God's presence and action: "Splendid and majestic is His work" (Ps 111:3; cf. Isa 40:5; 52:10). Ps 77:12-13 reads: "I will remember the works of the Lords; yes, I will remember Your wonders of old. I will reflect on all You have done and ponder Your mighty deeds." God's "work" is his mighty deeds, which are remembered in prayer, considered as "miracles" still "lasting" and having an effect beyond time (cf. Ps 44:2; 77:13; 143:5), and therefore glorified by successive generations (cf. Deut 32:4; Ps 64:10; 93:5; 11:3). The poet hopes that all of God's "servants" who have experienced a time of painful passing and are near the death will see His "work," namely, liberation from adversity, which will mean a time of peace between them and God. ${ }^{62}$ This extraordinary time, in which God will perform His "work" of liberation and give peace, will be shared not only by the praying man (in the present) but also by subsequent generations ("sons"). It is an essential reference to a future time. For God's "work" will become a future event and, at the same time, a timeless event, giving a new dimension to the passing time of subsequent generations. The "glorious power" of God revealed in His "work" will extend over the previously experienced time of anger. This is confirmed by the words of the prophet Habakkuk: "O Lord, I have heard the report of You, I stand in awe, O Lord, of

62 Cf. R. J. Clifford, "Psalm 90,” 204. 
Your deeds. Revive them in these years, make them known in these years. In Your wrath, remember mercy!" (3:2).

Given God's significant involvement, it can legitimately be argued that the Psalmist prays in the above-mentioned vv. 13-16 to complete the passing of the present time for essential aspects of God's "eternity." The prayerful man, who grants himself and his community (cf. "us" in v. 14-15:17) the title of "servant," actively requests the intervention of God, who "is from age to age" (v. 1) in the transient, short and wasted time for man. ${ }^{63}$ It can be concluded that in fervent prayer, he begs for the essential transformation of man's time by God. It is to be done by His dynamic gifts, in other words, by the actions of His renewed presence ("return!"-v. 13a): "mercy," "steadfast love," "joy," and "glorious power." Only He is their source when called by the prayerful man with the words of prayer as "You are" (v. 2). God, who is confessed and called out to in the prayer of supplication, responds to the transience and limitation, even insignificance and destructive character of time can transform with these wonderful actions. They introduce the experience of His own "eternity" (vv. 13-16; cf. Ps 145:2-21) into "time" (mentioned in vv. 3-10). Two more psalms in the fourth Psalter's collection after Ps 90 confirm that this is indeed the case. God listened to the prayer of supplication of the man from Ps 90:13-16 and answered with His actions: "For You, O Lord, have made me glad by Your deeds, I sing for joy at the works of Your hands" (Ps 92:5). ${ }^{64}$

\section{Bibliography}

Abelava, R., Le Psaume 90 et les fragilités humaines. Analyse sémantique et lecture contextuelle (Strasbourg: Université de Strasbourg 2012).

Aletti, J.-N. - Trublet, J., Approche poétique et théologique des Psaumes. Analyse et Méthodes (Paris: Cerf 1983).

Auffret, P., "Essai sur la structure littéraire du Psaume 90," Biblica 61 (1980) 262-276.

Baran, G.M., "Gniew Boży a gniew ludzki w świetle terminologii Pierwszej i Drugiej Księgi Machabejskiej," Verbum Vitae 33 (2018) 59-92.

Barr, J., Biblical Words for Time (Studies in Biblical Theology 33; London: SCM 1962).

Booij, T., "Psalm 90:5-6. Junction of Two Traditional Motifs," Biblica 68 (1987) 393-396.

63 Verse 16 is similarly interpreted by K. Seybold (“Zu den Zeitvorstellungen," 97-108, 99-100).

64 Cf. Köckert, "Zeit und Ewigkeit," 178f.; Erich Zenger ("The God of Israel's Reign," 164) sees in Ps 90 (vv. 3-10 and vv. 13-16) a strong difference between the time lived out by Gentile nations, even though they are created by God, and the time of the "servants" of God, of Israel. He writes: "If in Psalm 90, the tension is built up between universal mortality under God's 'wrath' and the full life of 'the servants of YHWH,' which comes from YHWH'S steadfast love and favor; this happens especially by reference to Psalm 102 (cf. especially Ps 102:24-28 [25-29]); probably also resonating here is the call of Israel as 'servant of YHWH' (developed in Isaiah) who has a special task of moving the nations to acknowledge YHWH'S reign." 
Botterweck, G.J., "dôr," Theological Dictionary of the Old Testament (eds. G.J. Botterweck H. Ringgren - H.J. Fabry) (Grand Rapids, MI: Eerdmans 1978) III, 169-181.

Castellino, G., Libro dei Salmi (Torino: Marietti 1955).

Clifford, R.J., Creation Accounts in the Ancient Near East and in the Bible (CBQMS 26; Washington, DC: Catholic Biblical Association 1994).

Clifford, R.J., "Psalm 90. Wisdom Meditation or Communal Lament?," The Book of Psalms. Composition and Reception (eds. P.W. Flint - P.D. Miller) (Leiden: Brill 2005) 190-205.

Forster, Ch., Begrenztes Leben als Herausforderung. Das Vergänglichkeitsmotiv in weisheitlichen Psalmen (Zürich: Pano 2000).

Gerlemann, G., “sb' - saziarsi,” Dizionario Teologico dell'Antico Testamento (eds. E. Jenni C. Wsetermann) (Torino: Marietti 1982) 738-741.

Gzella, H., Lebenszeit und Ewigkeit. Studien zur Eschatologie und Anthropologie des Septuaginta-Psalters (Bonner Biblische Beiträge 134; Berlin: Philo 2002).

Hossfeld, F.-L. - Zenger, E., Die Psalmen (Würzburg: Echter 2002) II.

Hossfeld, F.-L. - Zenger, E., Psalms. II. A Commentary on Psalms 51-100 (Minneapolis: MN, Fortress 2005).

Jenni, E., "Das Wort 'olam im Alten Alten Testament," Zeitschrift für die alttestamentliche Wissenschaft 64 (1952) 197-248.

Kinowski, K., “Motyw 'gniewu Bożego' w historiografii Ksiąg Królewskich,” Verbum Vitae 34 (2018) 37-66.

Köckert, M., "Zeit und Ewigkeit in Psalm 90," Zeit und Ewigkeit als Raum göttlichen Handelns. Religionsgeschichtliche, theologische und philosophische Perspektiven (eds. R.G. Kratz - H. Spieckermann) (Berlin: De Gruyter 2009) 155-185.

Kraus, H.-J., Psalmen, 7 ed. (Neukirchen-Vluyn: Neukirchener 2003) II.

Macintosh, A.A., "The Spider in the Septuagint Version of Psalm XC.9," Journal of Theological Studies 23 (1972) 113-117.

Muilenburg, J., “The Biblical View of Time," Harvard Theological Review 54 (1961) 225-271.

Müller, H.-P., "Der 90. Psalm. Ein Paradigma exegetischer Aufgaben," Zeitschrift für Theologie und Kirche 81 (1984) 265-285.

Oeming, M., Das Buch der Psalmen. Psalm 1-41 (Neuer Stuttgarter Kommentar, Altes Testament 13/1; Stuttgart: Katholisches Bibelwerk 2000).

Pritchard, J.B. (ed.), Ancient Near Eastern Texts Relating to the Old Testament, 3 ed. (Princeton: Princeton University Press 1969).

Ratschow, C.H., "Anmerkungen zur theologischen Auffassung des Zeitproblems," Zeitschrift für Theologie und Kirche 51 (1954) 360-387.

Ravasi, G., Il libro dei Salmi. II. Commento e attualizzazione (51-100) (Collana Lettura Pastorale della Bibbia 14; Bologna: EDB 1985).

Ruprecht, E., "שמח - rallegrarsi," Dizionario Teologico dell'Antico Testamento (eds. E. Jenni C. Wsetermann) (Torino: Marietti 1982) 749.

Schmidt, W.H., “'Der du die Menschen lässest sterben.' Exegetische Anmerkungen zu Ps 90,” Was is der Mensch...? Beiträge zur Anthropologie des Alten Testaments. Hans Walter Wolff zum 80. Geburtstag (eds. F. Crüsemann et al.) (München: Kaiser 1992) 115-130. 
Schmitt, R., Abschied von der Heilsgeschichte?Untersuchungen zum Verständnis von Geschichte im Alten Testament (Europäische Hochschulschriften 23, Theologie195; Frankfurt am Main: Lang 1982).

Schnocks, J., “"Ehe die Berge geboren wurden, bist du.' Die Gegenwart Gottes im 90. Psalm,” Bibel und Kirche 54 (1999) 163-169.

Schnocks, J., Vergänglichkeit und Gottesherrschaft. Studien zu Psalm 90 und dem vierten Psalmenbuch (Bonner biblische Beiträge 140; Berlin: Philo 2002).

Schreiner, S., "Erwägungen zur Struktur des 90. Psalms," Biblica 59 (1978) 80-90.

Sekine, M., "Erwägungen zur hebräischen Zeitauffassung," Congress Volume Bonn 1962 (eds. G.W. Anderson et al.) (Supplements to Vetus Testamentum 9; Leiden: Brill 1963) 66-82.

Seybold, K., “Zu den Zeitvorstellungen in Psalm 90,” Theologische Zeitschrift 53 (1997) 97-108.

Trublet, J., "La poétique des psaumes," Lumière et vie 202 (1991) 55-73.

Tułodziecki, T.,“'Dzisiaj kwiatem, jutro słomą' - tajemnica ludzkiego przemijania w Ps 90,” Verbum Vitae 24 (2014) 73-94.

Vesco, J.-L., Le Psautier de David. Traduit et commenté (Paris: Cerf 2006) II.

Wahl, H.M., "Psalm 90, 12. Text, Tradition und Interpretation," Zeitschrift für die alttestamentliche Wissenschaft 106 (1994) 116-123.

Wilch, J.R., Time and Event (Leiden: Brill 1969).

Witczyk, H., “Gniew Boga jak gniew człowieka?,” Verbum Vitae 33 (2018) 7-18.

Zenger, E., "Es sei deine Liebe, JH WH, über uns! Beobachtungen zu Aufbau und Theologie von Psalm 33,"》Gerechtigeit Und Recht zu uben« (Gen 18,19). Studien zur altorientalischen und biblischen Rechtsgeschichte, Religionsgechichte Israels und zur Religionssoziologie, FS E. Otto (eds. R. Achenbach - M. Arneth) (Wiesbaden: Harrasowitz 2009) 350-361.

Zenger, E., "The God of Israel's Reign over the World (Psalms 90-106)," The God of Israel and the Nations (eds. N. Lohfink - E. Zenger) (Collegeville, MN: Liturgical Press 2000) 161-190.

Zenger, E., “'Dem vergänglichen Werk unserer Hände gib Du Bestand!' Ein theologisches Gespräch mit dem 90. Psalm," Die Verantwortung des Menschen für eine bewohnbare Welt in Christentum, Hinduismus und Buddhismus (eds. R. Panikkar - W. Strolz Freiburg) (Herder: Freiburg im Breisgau - Basel - Wien 1985) 11-36. 
